\title{
The Silent Pandemic: Increased Initimate Partner Violence in Nigeria
} Obagboye, Tomi Grace ${ }^{1 *}$

\author{
${ }^{1}$ LL.B (University of Jos, Jos), LL.M, Kogi State University, Anyigba, Nigeria
}

DOI: $10.36348 /$ sijlcj.2022.v05i01.003

| Received: 02.07.2021 | Accepted: 05.08.2021 | Published: 22.01.2022

*Corresponding author: Obagboye, Tomi Grace

LL.B (University of Jos, Jos), LL.M, Kogi State University, Anyigba, Nigeria

\section{Abstract}

Intimate Partner Violence (IPV) has been identified as a global public health problem of human rights concern. It is a global issue with far reaching consequences for the physical, reproductive, and mental health of women, regardless of social, economic, religious or cultural group. Most of the times, IPV is usually perpetrated by a husband or an intimate male partner of a woman or girl and this is often due to the emotional attachment with or economic dependency of the women on the perpetrators of violence. The outbreak of the COVID-19 pandemic and the lockdown measure, although effective in reducing the disease spread has led to unintended negative consequences. The social, economic and financial distress experienced during the COVID-19 lockdown period has increased the prevalence of Intimate Partner Violence. The financial difficulty associated with the lock-down period has been known to precipitate stress and frustration, and subsequent negative coping mechanisms such as substance abuse and depression; all of which are baseline triggers for intimate partner violence. This has been labelled the silent pandemic. This article examines the rise in incidences of Intimate Partner violence in Nigeria during the COVID-19 Pandemic and contends that Individual Risk Factors, Financial Dependence on the Abuser, Poor Implementation of the rights of women, Cultural Perception of Women, Poor Governance and Resource Management, Lack of Adequate Social Welfare Palliative Schemes, in addition to the complications arising from dealing with COVID-19 pandemic are major factors that have resulted in the surge of Intimate Partner Violence in Nigeria. This work underscores recommendations to curb Intimate Partner violence in Nigeria during and beyond the COVID-19 pandemic, and ensure better realization of the rights and welfare of women and girls such as Legal Framework Reform, Socio Economic Empowerment of Women and girls, Community Mobilization and Behaviour Change Communication, Awareness Creation, and establishment of Sexual Assault Referral and Counselling Centres.

Keywords: Silent Pandemic, Intimate Partner Violence (IPV), COVID-19, Nigeria.

Copyright () 2022 The Author(s): This is an open-access article distributed under the terms of the Creative Commons Attribution 4.0 International License (CC BY-NC 4.0) which permits unrestricted use, distribution, and reproduction in any medium for non-commercial use provided the original author and source are credited.

\section{INTRODUCTION}

Intimate partner violence (IPV) is an international health and safety concern. It is a crisis in many nations that have taken the lives of both men and women. In Nigeria, like in many other African countries, gender relations have remained patriarchal in nature. IPV is pervasive throughout Nigeria and has a profound impact on both individual and the community $\left[{ }^{1}\right]$. Globally, over a third (35\%) of women has experienced physical and/or sexual violence by an intimate. Partner or sexual violence by a non-partner at some point in their lives $\left[{ }^{2}\right]$.

Previous studies from Nigeria have shown the prevalence of IPV to range from 31 to $61 \%$ for psychological/emotional violence, 20 to $31 \%$ for sexual violence, and 7 to $31 \%$ for physical violence $\left[{ }^{3}\right]$.

The outbreak of the COVID-19 has resulted in varying levels of distress among individuals. The social, economic and financial distress experienced during the COVID-19 lockdown period has led to unintended negative consequences such as social isolation, loneliness, inability of employers to pay their workers, job losses, increasing financial difficulties and increased the prevalence of Intimate Partner Violence. The financial difficulty associated with the lock-down period has been known to precipitate stress and frustration, and subsequent negative coping mechanisms such as substance abuse and depression; all of which are baseline triggers for intimate partner violence. 
The World Health Organization (WHO) defines IPV as any behavior within an intimate relationship by an intimate partner that causes physical, psychological, or sexual harm to those in the relationship. It is one of the most common types of violence experienced by women $\left[{ }^{4}\right]$. Most reported cases of IPV are perpetrated by men towards women. Though men can also be victims of IPV, it is not a common occurrence.

IPV includes acts of physical aggression (slapping, hitting, kicking, and beating), psychological abuse (intimidation, constant belittling and humiliation), forced intercourse and other forms of sexual coercion, various controlling behaviours (isolating a person from their family and friends, monitoring their movements and restricting their access to information or assistance).

The UN has defined intimate partner violence as "behaviour by an intimate partner or ex-partner that causes physical, sexual or psychological harm, including physical aggression, sexual coercion, and psychological abuse and controlling behaviours [ $\left.{ }^{5}\right]^{\text {", }}$

Intimate Partner Violence in Nigeria is increasingly becoming a pandemic threat to the wellbeing of women in society. IPV is pervasive throughout Nigeria and has a profound impact on both individual and the community $\left[{ }^{6}\right]$.

\section{COVID-19 AND INCREASE IN INTIMATE PARTNER VIOLENCE}

Intimate Partner Violence (IPV) transcends racial, social, and religious lines. This has manifested during the COVID-19 pandemic, where different countries, on different continents, have experienced a surge in the cases of IPV $\left.{ }^{7}\right]$. As nations scuffle to cope with the spread of the COVID-19 virus, another public health crisis is looming, as soaring evidence indicates that the conditions arise from the COVID-19 pandemic have led to a perfect environment for IPV to thrive $\left[{ }^{8}\right]$. Research conducted on the impacts of pandemics on domestic violence indicates that there is always an increase in male perpetrated IPV during emergencies, such as epidemics and pandemics $\left[{ }^{9}\right]$.

At least 15 million more cases of intimatepartner violence (for an average lockdown of six months) were predicted around the world as a result of pandemic restrictions, according to a report published by the UN Population Fund (UNFPA) and other organizations $\left[{ }^{10}\right]$.

The United Nations recently raised an alarm regarding the increase in reported cases of domestic and gender-based violence, directly attributed to forced proximity occasioned by lockdowns $\left[{ }^{11}\right]$.

In June 2020, in Nigeria, the Minister of Women's Affairs, Pauline Tallen told the public that the number of abuse cases against women and children had tripled as victims were trapped at home $\left[{ }^{12}\right]$.
The Director of the Lagos-based Women Advocates Research and Documentation Centre, Abiola Akiode-Afolabi, reported that since the lockdown started, the most common intimate partner violence reports recorded have been spousal violence, boyfriendgirlfriend violence, violence on widows, police-sex worker violence, and visitor-caught-in-lock-down child rape, among others $\left[{ }^{13}\right]$.

The Lagos State government-run Domestic and Gender Violence Response Team said it has been inundated with increased reports of sexual and domestic violence since the lockdown started late March. Most states have since relaxed the restrictions but many offices and schools have yet to fully reopen. TitilolaVivourAdeniyi, who leads the team, said at the peak of the lockdown in Lagos, the group on average received 13 new cases daily. In March alone, it received 390 reports. She further stated that there has been a $60 \%$ increase in domestic violence, $30 \%$ rise in sexual violence, and $10 \%$ increase in physical child abuse $\left[{ }^{14}\right]$.

Activists say the lock down has made it difficult for abused women to easily and quickly report attacks or reach the police. The lockdown also meant limited options for women to seek immediate assistance or help (beyond hotline calls), given women's restricted mobility as well as the limited health, legal, and social service infrastructure available $\left[{ }^{15}\right]$.

In addition, with quarantine and social distancing measures already in place in many countries throughout the world, many people have been confined to their homes for several weeks now with reduced freedom of movement. For those in volatile relationships, staying at home for such extended periods of time makes the home not a safe haven as such. During isolation, there is increased day-to-day exposure of victims to their violent partners hence an increased risk of IPV $\left[{ }^{16}\right]$. Spending extended time in close proximity with a spouse under circumstances of duress is known to increase IPV because even very minor issues can become a stressor or a trigger. Additionally, the unprecedented stress and anxiety triggered by the COVID-19 pandemic and the uncertainty about when it is all going to end, coupled with the economic uncertainty, have all escalated the rate of IPV in relationships with pre-existing IPV tendencies, as well as a risk factor for IPV for couples that were not in a violent relationship before.

The corona virus outbreak has exposed a silent pandemic of violence and inequality. The reality that women and men's needs differ, especially in a crisis as existing gender parities deepen, is still something that many don't understand. Current data suggests that women in the world's poorest countries are more exposed to the virus because of the roles they typically take on like serving as healthcare workers and caring for sick family members. Not only this but, as we have 
witnessed in Nigeria, Covid-19 has caused a significant surge in intimate partner violence around the world $\left[{ }^{17}\right]$.

In Nigeria, a series of high-profile cases of violence perpetrated against women during the fourmonth lockdown sparked nationwide protests by activists both online and at in-person rallies, this led to the Governors of Nigeria's 36 states unanimously declaring a state of emergency on GBV in June 2020.

As part of their declaration, the governors also called on all states to immediately launch sex offender registries and push for tougher federal punishment for abuse and violence against women. There has been other high-level engagement with the legislature to put in place strong laws against GBV in Nigeria $\left[{ }^{18}\right]$.

\section{FACTORS THAT ENGENDER INTIMATE PARTNER VIOLENCE}

\subsection{INDIVIDUAL RISK FACTORS}

Some individual risk factors for intimate partner violence include Low self-esteem, low income, low academic achievement, aggressive or delinquent behaviour as a youth, heavy alcohol and drug use, depression and suicide attempts, anger and hostility, lack of non-violent social problem solving skills, history of being physically abusive, unemployment, emotional dependence and insecurity, belief in strict gender roles(male dominance and aggression in relationships), hostility towards women, attitudes accepting or justifying IPV.

\subsection{FINANCIAL DEPENDENCE ON THE ABUSER}

Another study conducted in Nigeria revealed that the most prominent factor influencing intimate partner violence is financial discrepancies between partners, the influence of in-laws, and a couple within the same age group. All these aspects complement and fuel the belief that violence against those dependent on the man, should be subjected to violence in the name of discipline. The study also showed how IPV is an intergenerational phenomenon, with older generations affecting attitudes towards the treatment of women $\left[{ }^{19}\right]$.

Women have traditionally been entirely dependent on their husbands for finances, making them unable to survive on their own. Young women experiencing IPV, frequently do not possess any bodily autonomy or independence due to cultural practices. CHELD's founder and executive, founder, Cheluchi Onyemelukwe-Onuobi, identified economic inequality between men and women as a major factor in IPV, claiming that women have insufficient funds to spread infor-mation about inequality through making calls and buying airtime. Within the home, the concept of men as the sole breadwinners prevents women from leaving their abusers. "Many of the women have been beaten down and prevented from working and earning any income to keep them financially dependent on the abuser" $\left[{ }^{20}\right]$.

\subsection{POOR IMPLEMENTATION OF WOMEN RIGHTS}

Nigeria has well equipped policy frameworks to achieve gender equality and social inclusion. The country is a signatory to a number of key global and regional instruments to tackle gender inequality and social exclusion. Some of these include: The Convention on the Elimination of All Forms of Discrimination against Women (CEDAW 1979); TheBeijing Platform for Action (1995); The Millennium Development Goals (2000); The Protocol to the African Charter on Human and People's Rights on the Rights of Women in Africa (2005); and The Convention on the Rights of Persons with Disabilities (CRPD 2006). Nigeria also passed the Child Rights Act in 2003, which has been domesticated so far in 18 states. Above all, Nigeria's National Gender Policy (2006) was agreed to and adopted by all states in Nigeria to promote gender equality and inclusiveness in development.

The Ministries Departments and Agencies (MDAs) have the task to translate policy proclamations to programs of action, budget for them and ensure their implementation. However, the reality is that, the policies are yet to be translated into programs to benefit the people for whom they were formulated. It is therefore important to give full financial and material support to the relevant sector MDAs to design programs that will make the policies real for the people.

There are several laws in Nigeria that protect the rights of women in Nigeria. Despite these laws, women and girls suffer abuse of their rights on a daily basis. This is due to ignorance of the rights of women and lack of political will by the government to implement the rights of women.

\subsection{CULTURAL PERCEPTIONS OF WOMEN}

Scholars argue that violence against women is an expression of patriarchal domination of women by men, rooted in gender and power inequality. In some societies, men are the breadwinners, while women are expected to be homemakers, to care for the children, and to be economically dependent on the men. When changes occur in the traditional gender order and roles, violence can result, particularly in patriarchal societies $\left[{ }^{21}\right]$. For example, if a wife disobeys or challenges her husband or does not play her gendered role, the husband may resort to violence to discipline her. He does this to put her in her place and to maintain his power and control.

\subsection{POOR GOVERNANCE AND RESOURCE MANAGEMENT}

Good governance refers to the exercise of authority through political and institutional processes that are transparent and accountable and encourage public participation.

Without good governance, human rights cannot be respected and protected in a sustainable manner. The 
implementation of human rights relies on a conducive and enabling environment. This includes appropriate legal frameworks and institutions as well as political, managerial and administrative processes responsible for responding to the rights and needs of the population. States are responsible for delivering a variety of services to their populations, including education, health and social welfare services. The provision of these services is essential to the protection of human rights such as the right to housing, health, education and food. Human rights principles dictate that public services should be available, accessible and culturally acceptable in order to secure the rights of the poorest and most marginalized. Good governance contributes to this goal by approaching individuals as actors in and not just beneficiaries of economic and social development $\left[{ }^{22}\right]$.

There is no doubt that nurturing good governance is essential to ensuring respect for human rights. Without the rule of law, independent courts and other institution of modern society- essential components of good governance- the promise of human rights may remain just that: a promise unfulfilled. Enforcement of fundamental freedoms when it matters may be impossible. The lesson of history is that transparent, responsible, accountable and participatory governance is a prerequisite to enduring respect for human dignity and the defense of human rights $\left[{ }^{23}\right]$.

Bad leadership refers to greedy and selfish political leaders who only pay lip service to the welfare of its citizens without showing any political will to implement and enforce laws that will better the lives of the people.

The political leaders must develop robust interest in the welfare and wellbeing of their citizens as a demonstration of fulfilling the mandate freely given to them during elections. Unfortunately, it appears one of the major issues that have encouraged lack of political will by the leaders is the pervasive influences of public corruption which has been endemic since the onset of democracy in Nigeria.

An Elder Statesman, Banji Akintoye, aptly captured the adverse effect of corruption in the country. He said "This is how we have become what we now arenamely, a country where public officials steal trillions of naira, where some politicians pocket billions of naira or even dollars in loot, where powerful citizens buy million -dollar houses for their concubines abroad, where governors and their cronies buy jet aircrafts for their personal use, where federal legislators earn more than the President of America, where more than $70 \%$ of citizens live in absolute poverty, where the lack of infrastructures massively discourages enterprise, where more than $70 \%$ of youths are unemployed, where crime had virtually destroyed all sense of security, etc"
The welfare of citizens which is one of the primary purposes of government is jettisoned by the governors as they get involved in aggrandizement and personal enrichment, thus creating a class mentality for themselves and their children at the expense of the ordinary citizens.

Closely linked to the foregone is the issue of poor management of natural resources. Nigeria is the largest oil producer in Africa and the tenth largest producer of crude oil in the world. It is quite amazing that the stupendous resources gained from oil have not been reflected in the rate and level of development in Nigeria. Rather, such resources have not been properly managed but wasted. These factors have created a situation of poverty, reduction in the quality of lives of citizens and a general sense of financial tension. Many men are unable to meet all their financial obligations. Consequently, a man could abuse his wife or partner at any slightest real or perceived provocation.

\subsection{LACK OF ADEQUATE SOCIAL WELFARE AND PALLIATIVE SCHEMES}

In a bid to slow the rate of the spread of the virus, the Federal Government of Nigeria, on several occasions, imposed targeted lockdown measures in areas with rapid increase of Covid-19 cases. To alleviate the effects of the lockdown, the Federal Government of Nigeria rolled out palliative measures for targeted groups. However, lamentations have trailed the distribution of government palliatives by the masses. Nigerians allege that the process of distribution of the palliatives had been politicized. The Federal Government had earlier said that the palliatives were for the most vulnerable in the society, though there were no laid down parameters for determining the most vulnerable $\left[{ }^{24}\right]$.

The lockdown and poor distribution of palliative items simple brought to the fore the lack of adequate social welfare and efficient palliative schemes in Nigeria. This resulted in untold hardship on the citizens and led to frustration in many homes. Various forms of violence against women became rampant, as men turn their aggression against women they can no longer control or support economically.

\section{RECOMMENDATIONS/CONCLUSION 4.1 LEGAL FRAMEWORK REFORMS}

Reforming legal frameworks may include strengthening women's civil rights. Improving existing laws and their implementation may curb violence by signaling what are socially unacceptable and strengthening sanctions against perpetrators. Some steps in this direction include: strengthening and expanding laws defining rape and sexual assault within marriage, sensitizing and training police and judges about partner violence; and improving the application of existing laws. There are several laws that protect the rights of women in Nigeria. However, many women and girls are ignorant of their rights. There is a need for massive orientation on 
the rights of women. In addition, the Government should show a greater commitment and will to protect and enforce the rights of women. In addition, other relevant international and regional treaties which have been ratified by the country should be domesticated. For example, the Convention on the Elimination of All Forms of Discrimination against Women (and its optional Protocol) and Protocol on Women's Rights in Africa should be domesticated. Presently, only the African Charter on Human and Peoples Rights has been domesticated into Nigerian law.

\subsection{SOCIO- ECOMOMIC EMPOWERMENT OF WOMEN AND GIRLS}

Women and girls should be empowered socially and economically. This would make them less financially dependent on their partners and reduce the risk of IPV. There is emerging evidence that interventions combining microfinance with gender-equality training may be effective at reducing levels of IPV. Social safety nets such as food and cash supply should be provided to lowincome members of the population to mitigate the economic burden which may culminate in Intimate Partner Violence.

\subsection{COMMUNITY MOBILIZATION AND BEHAVIOUR CHANGE COMMUNICATION}

Mass media 'edutainment' strategies (e.g. programs that use multimedia such as television, radio and print) to change social norms and mobilize community-wide changes have been shown to influence gender norms, community responses and individual attitudes to IPV. Many non-governmental organizations have used community mobilization, community education and mass media strategies to address violence against women, and the evidence base about effective programming in this area is increasing. There are also promising initiatives to engage men and boys in violence prevention, as well as other community-based programs that aim to reduce IPV along with HIV transmission, such as Stepping Stones, a program that has been replicated in settings all over the world. The provisions of Article 5 of the CEDAW are instructive. It provides as follows:

\section{States Parties shall take all appropriate measures}

(a) To modify the social and cultural patterns of conduct of men and women, with a view to achieving the elimination of prejudices and customary and all other practices which are based on the idea of the inferiority or the superiority of either of the sexes or on stereotyped roles for men and women;

(b) To ensure that family education includes a proper understanding of maternity as a social function and the recognition of the common responsibility of men and women in the upbringing and development of their children, it being understood that the interest of the children is the primordial consideration in all cases.
This emphasizes the fact that there is a need to take measures to eliminate cultural and social prejudices against women and carry out regular re-orientation on the role and status of women in the society. The Mass media should project programs and views that support equality for all Nigerians.

\subsection{AWARENESS CREATION}

There is a need to build the knowledge base and raise awareness. Although there is a growing body of knowledge about the magnitude, patterns and risk factors associated with IPV, many research gaps remain, including patterns of women's responses to violence and the effects of IPV on children. Expanding the knowledge base and disseminating existing and new information will lead to better programs and strategies. Data on prevalence and patterns can also be important tools to engage governments and policy-makers in addressing this issue.

\subsection{SEXUAL ASSAULT REFERRAL AND COUNSELLING CENTRES}

The establishment of many Sexual Assault Referral and Counselling Centers also known as One Stop Centers in every state, should be encouraged, where all criminal justice services and other welfare services, including prompt free medical care, support, free legal aid, counselling and rehabilitation services can be rendered to victims to sexual offences at the same place to reduce secondary victimization and increase the rate of reporting sexual offences. Support Systems such as counselling and psychotherapy sessions should be instituted for victims of violence. Dr. Olumuyiwa Ojo, the WHO Nigeria National Professional Officer for Maternal, Sexual and Reproductive Health, stated that there is a need for mainstreaming GBV services and linking survivors to other services.

\section{REFERENCES}

\begin{abstract}
${ }^{1}$ Tayo Aderibigbe, Preventive Approach to Intimate Partner Violence in Nigeria, Diconia University of Applied Sciences, obtained from https://www.theseus.fi/bitstream/handle/10024/265590/A deribigbe_Tayo.pdf

${ }^{2}$ World Health Organization. Global And Regional Estimates Of Violence Against Women Prevalence And Health Effects Of Intimate Partner Violence and Nonpartner Sexual Violence [Internet]. World Health Organization. Italy: World Health Organization; 2013 [cited 18 Feb 2018]. Available from: http://www.

who.int/reproductivehealth/publications/violence/978924 1564625/en/

${ }^{3}$ Mapayi, B., Makanjuola, R.O.A., Mosaku, S.K., Adewuya, O.A., Afolabi, O., Aloba, O.O. Impact of intimate partner violence on anxiety and depression amongst women in Ile-Ife, Nigeria. Arch Womens Ment Health [Internet]. 2013 [cited 18 Feb 2018]; 16(1):11-18. Available from: https://www.researchgate.net/publication/230768882_Im
\end{abstract}


pact_of_intimate_partner_violence_on_anxiety_and_dep ression_amongst_women_in_Ile-Ife_Nigeria.

${ }^{4}$ World Health Organization. World Report on Violence and Health [Internet]. Krug EG, Dahlberg LL, Mercy JA, Zwi AB, Lozano R, editors. Geneva: World Health Organization; 2002 [cited 18 Feb 2018]. Available from: http://apps.who.int/iris/bitstream/handle/10665/42495/92 41545615_eng.pdf?sequence $=1$

${ }^{5}$ UNITED NATIONS 2019

${ }^{6}$ Solanke, B. L. (2018). Does Exposure to Inter -Parental Violence increase Women's risk of Intimate Partner Violence? Evidence from Nigeria demographic and health survey. BMC International Health and Human Rights, 18(1), 1. https://doi.org/10.1186/s12914-0180143-9.

${ }^{7}$ Peterman, A., Potts, A., O’Donnell, M., Thompson, K., Shah, N., Oertelt- Prigione, S. (2020). Pandemics and violence against women and children. Washington, DC: Center for Global Development Working Paper 528 April 2020. Available at: https://www.cgdev.org/sites/default/files/pandemics-andvawg.pdf. Accessed Jul 9, 2020.

${ }^{8}$ World Health Organization COVID-19 and violence against women. Available at: https://apps.who.int/iris/bitstream/handle/

10665/331699/WHO-SRH-20.04-eng.pdf. Accessed Jul 9,2020.

${ }^{9}$ Fraser, E. (2020). Impact of COVID-19 pandemic on violence against women and girls. London, UK: VAWG Helpdesk Research Report No. 284. Available at: https://cieg.unam.mx/covid-genero/

pdf/reflexiones/academia/impact-of-covid-pandemic.pdf. Accessed Jul 9, 2020.

${ }^{10}$ TorinmoSalau, Addressing Surging Gendered Violence in locked down Nigeria. Women's Media Centre, July, 17,2020 obtained from www. Womensmediacentre.com. Accessed on 10 ${ }^{\text {th }}$ May, 2021.

${ }^{11}$ Ejiro Umukoro, Amid COVID-19 Lockdown, Nigeria Sees Increased Sexual and Gender Violence, Premium Times, June 5,2020.

${ }^{12}$ Torinmo Salau, N 10

${ }^{13}$ Ejiro Umukoro. N 11.

${ }^{14}$ Ibid.

${ }^{15}$ Fawole, O.I., Okedare, O.O., \& Reed, E. (2021). Home was not a safe Haven: Women's Experiences of Intimate Partner Violence during the COVID-19 lockdown in Nigeria. BMC Women's Health, 21, 32.
${ }^{16}$ Bradbury-Jones, C, Isham, L. (2020). The pandemic paradox: The consequences of COVID-19 on domestic violence. J Clin Nurs, 29(13-14):2047-9.

${ }^{17}$ Lola Ayanda,'Women are Fierce but Afraid. Covid-19 has exposed a Silent Pandemic of Violence.' $14^{\text {th }}$ July, 2021 obtained from https://nigeria.actionaid.org/stories. Accessed on 8/06/2021.

${ }^{18}$ WHO Supports Government to Curb Gender-Based Violence obtained from www.afro.who.int/news/who

${ }^{19}$ Aihie, O. (2010). Prevalence of Domestic Violence in Nigeria: Implications for Counselling. Edo Journal of Counselling, 2(1). doi: 10.4314/ejc.v2i1.52648.

${ }^{20}$ Usigbe, L. (ed.). Nigerian women say 'no' to genderbased violence. Africa Renewal. Retrieved August 20, 2019, from https://www.un.org/africarenewal/news/nigerian-women-say-'no'-gender-based-violence.

${ }^{21}$ Faith Owunari Benebo, Barbara Schumann and Masoud Vaezghasemi, Intimate Partner Violence against Women In Nigeria: A Multilevel Study Investigating The Effect of Women's Status and Community Norms, BMC Women's Health (2018) 18:136 https://doi.org/10.1186/s12905-018-0628-7.

${ }^{22}$ Good Governance Practices for the Protection of Human Rights, Office of the United Nations High Commissioner for Human Rights, New York to Geneva, 2007.

${ }^{23}$ The Hon. Justice Michael Kirby AC CMG, "Human Rights- Essential for Good Governance" Seminar on Good Governance for the Protection of Human Rights held in Seoul, Republic of Korea, 15 September 2004. Electronic copy available at: <www.sandstonespress.net/olr/OLR_sample.pdf>.

${ }^{24}$ Isaac, O. (2020). Eranga, COVID-19 Pandemic in Nigeria: Palliative Measures and the Politics of Vulnerability. International Journal of Maternal and Child Health and AIDS, 9(2); 220-222 